\title{
EMPHATY AND TOLERANCE IN PHYSICAL EDUCATION: COOPERATIVE VS. CLASSICAL LEARNING
}

\author{
Sri Winarni ${ }^{1 *}$, Rusli Lutan ${ }^{2}$ \\ ${ }^{1}$ Universitas Negeri Yogyakarta, Indonesia \\ ${ }^{2}$ Universitas Pendidikan Indonesia, Indonesia \\ *e-mail: sri_winarni@uny.ac.id
}

\begin{abstract}
There is a common belief that physical education is potential to introduce moral values, such as emphaty and tolerance. However, belief itself is still debatable and needs more empirical evidence. This experimental study aimed to examine the effectiveness of two learning methods commonly used in physical education, namely cooperative and classical learning, whether they could be used to embed the moral values. A total of 128 eight graders (52 boys and 76 girls) involved in the experiment. These students were categorised as above average in academic, diversed in religion and social economy background, but they are mostly Javanese. The emphaty was measured using Baron-Cohen scale, while the tolerance was measured using the instrument developed by UNESCO. The data were analysed using a $2 \times 2$ factorial design varying learning model (cooperative vs. classical) and academic achievement (international class vs. regular class). The results showed that cooperative learning was significantly more effective than classical learning. It was found that the emphaty and tolerant scores of the leading class was significantly higher than those in the reguler class. It might be said that those with high cognitive ability may also develop moral values. Nevertheless, no interaction effect was found. This results are discussed using the perspective of socio-constructivism.
\end{abstract}

\section{Keywords: cooperative learning, classical, physical education, emphaty, tolerance}

\section{EMPATI DAN TOLERANSI DALAM PENDIDIKAN JASMANI: PEMBELAJARAN KOOPERATIF VS. KLASIK}

\begin{abstract}
Abstrak: Ada keyakinan bahwa pendidikan jasmani berpotensi untuk memperkenalkan nilai-nilai moral seperti empati dan toleransi. Namun, keyakinan tersebut masih bisa diperdebatkan dan membutuhkan lebih banyak bukti empiris. Penelitian ini bertujuan untuk menguji efektivitas dua metode pembelajaran yang biasa digunakan dalam pendidikan jasmani, yakni pembelajaran kooperatif dan klasik karena keduanya dapat digunakan untuk membelajarkan nilai-nilai moral. Ada 128 siswa (52 laki-laki dan 76 perempuan) yang terlibat dalam penelitian ini. Siswa-siswa ini berkemampuan di atas rata-rata dalam bidang akademik, beragam dalam latar belakang agama dan sosial ekonomi, tetapi kebanyakan dari mereka adalah suku Jawa. Empati diukur menggunakan skala Baron-Cohen, sedangkan toleransi diukur menggunakan instrumen yang dikembangkan oleh UNESCO. Penelitian menggunakan desain faktorial $2 \times 2$ (kooperatif vs klasik) dan prestasi akademik (kelas internasional vs kelas reguler). Hasil penelitian menunjukkan bahwa pembelajaran kooperatif secara signifikan lebih efektif daripada pembelajaran klasik. Ditemukan bahwa skor empati dan toleransi dari kelompok yang berprestasi tinggi secara signifikan lebih tinggi daripada yang di kelas reguler. Maka, dapat dikatakan bahwa mereka yang memiliki kemampuan kognitif tinggi juga lebih dapat mengembangkan nilai-nilai moral. Namun demikian, tidak ditemukan efek interaksi. Hasil ini dibahas dengan menggunakan perspektif sosio-konstruktivisme.
\end{abstract}

Kata Kunci: pembelajaran kooperatif, pembelajaran klasik, pendidikan jasmani, empati, toleransi

\section{INTRODUCTION}

Research on Physical Education cooperative learning over the past 5 years has focused more on secondary education, especially in short-term interventions. Qualitative and/ or mixed methods are used in most studies and even handling with exercise, motor skills, and physical abilities, making bodily expressions under-represented. social learning is the goal most frequently researched, focusing on 
motivation, group climate, and teacher-student interaction (Bores-garcía, Hortigüela-alcalá, Fernandez-rio, González-calvo, \& Barba-martín, 2020). Recently, the issue of character building has widely spread including belief that physical education should take part to contribute. Schools may seem ideal places to teach children about tolerance and harmony as stated by Pfeifer, Brown, \& Juvonen (2007) in Society for Research in Child Development about Teaching Tolerance in Schools: Lessons Learned Since Brown v. Board of Education about the Development and Reduction of Children's Prejudice

Discussions on this topic have been started decades ago. Schaps, Battistich, \& Solomon (1997) stated that concept of affective development as the objective of physical education has been introduced since more than 160 years ago, and problem with morality occurs usually when students are challenged to balance their right and obligation with these of the others. Kleiber \& Robert (1981) indicated that children who participated in competitive sports tend to decrease their prosocial behavious. Shields \& Bredemeier (1995) argued that maturity in moral reasoning of athletes is lower that that of nonatheletes in the same age, while Orlick (1981) found that physical activity gives positive impact to their cooperative attitude. Environment may internalize values to oneself (Maksum, 2007; Bredemeier \& Shields, 2006: Weinberg \& Gould, 2003). Nevertheless, character building requires a process of reorganization and transformation of basic reasoning structures already possessed (Maksum, 2007; Bredemeier \& Shields, 2006).

Arguably, there are two character values, tolerant and emphaty, that are presumably could improve quality as an individual in terms of building relationship with others. Bolton (1979) stated that emphaty is an ability to see and listen to others in order to understand the happenings from the perspective of the others. Emphaty is important to build constructive communication. It is oneself responsibility to develop emphaty (Zuchdi, 2008). Having emphaty, at work in particular, also motivates other workers to accomplish their job tasks.

Turning to tolerant, generally it is seen as representation of character to respect or accept opposite opinion, ideas, belief, habit, attitude, or even religion (Pusat Bahasa Departemen Pendidikan Nasional Republik Indonesia, 2008).
Similarly, UNESCO (1995) explained tolerance as respect, acceptance and appreciation for all kind of differences with regard to culture, expressions or way of life. Tolerance is respect, acceptance, and appreciation for so many differences in terms of culture, the form of one's expression and the way or way of being human. That includes knowledge, openness, communication, and freedom of thought, conscience and trust. Tolerance is a harmony in differences. Tolerance is not only a moral obligation, but also a political and legal requirements. Tolerance is a virtue that makes world peace possible, transforming war culture into a culture of peace.

Tolerance, in a broad sense, can be understood as "Accepting differences" (Knauth, 2010). In line with this opinion, Knauth (2010) explained that tolerance is widely regarded as a common shared value that is indispensable to guarantee the cohesiveness of a plural society. This is based on findings about the tradition of conflict, division and separation between people from different cultural and religious backgrounds, partly rooted in the development of nation states in Europe and partly rooted in the colonial role of these countries. As long as the traditions and practices of social intolerance and exclusion are not overcome, social cohesion in society is threatened with extinction. According to Knauth (2010) tolerance is based on two conditions: first, there must be a situation of difference or plurality, and second, there must be some reason for passively or actively accepting (even respecting) a situation of difference. Taking the concept of broader scope, tolerance is to analyze the understanding of differences or plurality which are various situations of tolerance, and various different theories and reasons for accepting (or not accepting) this diversity. In this way we can also get a more precise understanding of "tolerated", which is the right tolerance limit.

Tolerance is respect, acceptance, and appreciation for so many differences in terms of culture, the form of one's expression and the way or way of being human. That includes knowledge, openness, communication, and freedom of thought, conscience and trust. Tolerance is harmony/harmony in differences. This is not only a moral obligation, but also political and legal requirements. Tolerance is a virtue that makes world peace possible, 
transforming war culture into a culture of peace. United Nations Educational, Scientific and Cultural Organization (UNESCO) Article 4 of the declaration of tolerance states that education is the most effective way to prevent intolerance. The first step in tolerance education is to teach people about their shared rights and freedoms, so they can be respected, and to promote to protect others. Furthermore it is mentioned that education for tolerance must be considered as an urgent necessity, that is why it is necessary to promote systematic and rational methods of teaching tolerance that will address cultural, social, economic, political and religious sources as intolerance, the main roots of violence and exclusion. Educational policies and programs must contribute to the development of understanding, solidarity and tolerance between individuals and among ethnic, social, cultural, religious and linguistic and national groups.

There are four ways to teach tolerance to children (Allport, 1960). First, introduce diversity. Start by giving an understanding that there are various ethnicities, religions, and cultures. Tell the child even though other people have different religions or tribes, humans are actually the same and cannot be discriminated against. Introducing diversity as early as possible can later foster a spirit of tolerance for children to better see differences that exist more wisely. Secondly, differences are not for hatred. Teach children that differences exist, don't respond to hatred, because hatred will make people sad and hurt others. Try to encourage children to assume if they are hated because of differences, they will certainly feel sad. With that, they feel more empathy and tolerate what others feel. Third, give an example. Don't just tell him through words, but also real examples. If you meet someone using religious symbols that are quite extreme or someone who has a different skin color, don't look at him with strangeness, let alone say something hateful and teasing. Fourth, tolerate for peace. Tell students that tolerance is needed. If there is no tolerance, many people will be hostile and hate one another. Explain if that happens, it will not be comfortable when attending school or playing.

Wuest \& Bucher(1995) stated that physical education is an education process. The physical education cannot be apart from education since it affects individual development to the potential, and to be a human being (Harisson \& Blackmore, 1989). Contributing factors to the impact of physical education might include teacher quality and model of learning that will directly influence how students build their cognitive structure on the moral values (Hardman, 2003; Clifford \& Feezell, 1997).

It is widely agreed that competent teachers are those who are able to teach meaningfully using creative and innovative methods. In fact, however, many teachers use monoton, one way teaching methods to drill knowledge on specific skills in sports, without comprehensive evaluation (Maksum, 2005). Accordingly, teachers should devote some efforts to implement various method of teaching.

Lickona (1991) asserted that character education can be facilitated using cooperative learning since character education is more focused on building social skills, not just cognition. Slavin (2005) argued that the foci of cooperative learning is to gather students in heterogeneous groups and usually be conducted in several weeks or months. The success of cooperative learning might depend on several factors, such as positive interdependance, face-to-face interaction, individual and group accountability, inter and intrapersonal skills and group processing (Johnson, Johnson, \& Holubec, 1993). Therefore, implementing cooperative learning should take these factors into account by making sure whether the group members understand their role. Cooperative learning creates positive interpersonal relationships characterized by personal and academic support and promotes greater psychological health and well-being (including self-esteem and social competencies) (Johnson, Johnson, \& Smith, 2013).

The decrease of emphaty and tolerance among teenagers should become our concerns, for example, street fighting among students, sport supporters, between religion followers or the others. There could be many reasons behind this social disharmony, perhaps the failure to understand differences on culture, language, gender, ethnic, and religion triggers the subjective behaviour such as disrespectful, forcing others, egoicetrism, dispoointed and angry.

Another social changes may be created by school system. Recently, there have been selected schools that accept top students, and 
facilitate acceleration. It has been heard that these students tend to think that they are different than those in regular classes. This can also be seen in the classroom that they like to compete with the others. It has been observed by the researchers that emphaty and tolerance started to disappear in the selected classes. For an example, they do not care of each other when their classmate needs help for completing tasks, or sick. Sharing was also getting less. In short, it seems like becoming part of selected class made the loose of emphaty and tolerance. This behaviour disregards the importance of values and character building during school. Indeed, moral belief may depend on cognitive ability (Weinberg \& Gould, 2003). The accelerated class contains students with cognitive achievement above average, but more competitive to the others.

Based on the background of the problem as described above it can be said that through cooperative learning in values-based physical education there is experience available to develop moral values of empathy and tolerance that can be achieved through positive dependence and interaction with other students. Through real experience in dealing with and listening to others, it is hoped that core values can be achieved to bring about peace, respect for others, tolerance, cooperation, responsibility, solidarity, discipline, honesty are part of fostering the character of the nation and character building. The embodiment of the core values of physical education will not be separated from the teacher's role in managing learning, namely learning that is more centered on students who are more actively learning with cooperative learning together and experience more experiences on the value of empathy and tolerance, than on the other hand centered on material and the teacher is more active with classical learning.

\section{METHODS \\ Design}

This quasy experiment used a 2 by 2 factorial design involving academic achievement (international class vs. Regular class) and learning model (cooperative learning vs. classical learning).

\section{Participants}

There were 128 students (AGE 13-14 years old) participated in the research voluntary, differ in terms of ethnicity, races, and religion, however the participant's intelligence level are quite similar, they were choosen from a selected school in Yogyakarta, Indonesia. All students had used the same curriculum of physical education. This participants can be seen in the Table 1 .

\section{Data collection}

Emphaty and tolerance were measured using a psychology scale adopted from Empathy Quotien by Simon Baron-Cohen (2003) consisting of 60 items (40 items for emphaty and 20 distracting items), permission granted. This tool was translated into Indonesian languange, as the participants are native Indonesian. Face validity was conducted to test whether the translation has correct readibility. Meanwhile, the tolerance instrument used in this research was from the UNESCO (REF), consisting of 13 items. The Empathy Quotient from Simon Baron-Cohen was chosen since it can be used for all age level and psychological development, as well as it has high reliability (Alpha Cronbach $=$ .97). The tolerance quotient has reliability .8333.

Table 1. Groupings of Participant based on the Learning Model

\begin{tabular}{lccl}
\hline \multirow{2}{*}{\multicolumn{1}{c}{ Groupings }} & \multicolumn{2}{c}{ Number of } & \multicolumn{1}{|}{ Learning Model } \\
\cline { 2 - 3 } & Boys & Girls & \\
\hline Selective class - cluster 1 & 11 & 15 & Cooperative learning \\
Selective class - cluster 2 & 11 & 15 & Classical learning \\
Reguler class - cluster 1 & 14 & 24 & Cooperative learning \\
Reguler class - cluster 2 & 16 & 22 & Classical learning \\
\hline
\end{tabular}




\section{FINDINGS AND DISCUSSION Findings}

Data on the measurement of empathy and tolerance were carried out twice, namely at the beginning and at the end of treatment. The results of the multivariate analysis of variance (Manova) significance test showed that the significance value on the learning model variable $p=.01<.05$ which can be concluded that there is an influence of the learning model on the moral values of empathy and tolerance. Likewise the type of class shows the value of $p=.00<.05$ which can be concluded that there is an influence of class type on the moral values of empathy and tolerance. But there is no effect of the interaction of class types with the learning model together on the moral values of empathy and tolerance, because the value of $p=.231>.05$.

Table 2 shows that there were differences in empathy scores between the four groups. Significant increase in the average empathy score occurred in three groups except in the regular group using the classical learning method.

Table 3 shows that there were no significant differences between the average scores of tolerance in all groups. In all groups, there were an increase in the average tolerance score at the pre-test and post-test but not significant.

\section{Discussion}

The results of the research hypothesis test shows that there are differences in cooperative and individual learning models in developing student empathy and tolerance, this means that physical education learning that is packed with cooperative learning makes it easy for students to build their moral values of empathy. As a learning model, cooperative learning has been planned with a pattern of group learning strategies that involve group collaboration, individual and group interactions, group responsibilities lead to social situations that are able to present various scenes of empathy (understanding and feeling what other people feel).

Comparative studies on goal-free problems have been studied between individuals and collaborative learning. Although it was found that individual learning scored significantly higher than collaborative learning; however, during the acquisition phase, individuals experience a cognitive load is much higher than collaborative learning. No interaction effect patterns were shown. (Sugiman, Retnowati, Ayres, \& Murdanu, 2019). Direct experience that provides a variety of social situations in physical activity, the ability to assimilate new concepts (concepts of empathy) and reflect them in the form of behavior that students perceive as acts of empathy, it is very possible that the moral values of empathy flourish. This is in line with the opinion that socialization can affect children's empathy through providing opportunities to play the role of others in positive contexts that can help sharpen cognitive sensitivity to others and help children pay more attention to others so as to enhance and expand their empathic abilities (Hoffman, 1982 in Kurtines \& Gerwitz, 1992).

Table 2. Interaction of Differences in Mean Values of Empathy

\begin{tabular}{lcccccc}
\hline \multirow{2}{*}{\multicolumn{1}{c}{ Grouping }} & \multicolumn{5}{c}{ Tolerance Mean } & \multicolumn{1}{c}{$\boldsymbol{F}$} \\
\cline { 2 - 7 } & Pre-test & SD & Post-test & SD & Count & Table (.05) \\
\hline International-Cooperative & 39.2308 & 7.9363 & 49.5385 & 4.6753 & & \\
International-Classical & 38.1923 & 6.7053 & 42.8846 & 7.1678 & 7.5222 & 3.9224 \\
Regular-Cooperative & 37.7632 & 7.0727 & 41.5789 & 6.8522 & & \\
Reguler-Classical & 37.8333 & 8.1504 & 38.8889 & 7.5962 & & \\
\hline
\end{tabular}

Table 3. Interaction of Difference in Mean Tolerance Value

\begin{tabular}{lcccccc}
\hline \multirow{2}{*}{ Grouping } & \multicolumn{5}{c}{ Tolerance Mean } & \multicolumn{1}{c}{$\boldsymbol{F}$} \\
\cline { 2 - 7 } & Pretest & SD & Post-test & SD & Count & Table (.05) \\
\hline International-Cooperative & 20.3462 & 2.7414 & 21.5385 & 2.1583 & & \\
International-Classical & 19.6538 & 2.6221 & 20.8846 & 2.2508 & & \\
Regular-Cooperative & 18.5000 & 3.0910 & 20.4737 & 3.1083 & 2.9912 & 3.9224 \\
Reguler-Classical & 18.6389 & 2.6635 & 19.7778 & 2.5536 & & \\
\hline
\end{tabular}


Timpe argues that interactions with groups who follow feelings sensitivity training will increase feelings sensitivity so they have higher empathy (Zuchdi, 2008). Likewise with Carl Rogers who argues that to build constructive communication relationships requires empathy which is able to feel what is felt by others without being influenced by that person. Empathy consists of a combination of understanding other people, understanding the situation, and how to communicate with others (Bolton, 1979). A person's empathy not only helps constructive change, but also helps that person develop his personality in a positive direction (Bolton, 1979; Zuchdi, 2008). Empathy is one thing that can predict cognitive flexibility significantly while interest in reading do not (Certel, Bahadır, Kabaca, \& Seraki, 2018). Furthermore, students' empathy abilities are affected by sports training (Yigiter \& Pelin, 2013).

One important target in teaching empathy and tolerance is to teach and practice systematically on each lesson. Thus, schools are seen as a place to develop the values needed to live a good life. Humanist education system, which is able to position students as individuals and community members who need to be assisted and encouraged in order to have effective habits, a combination of knowledge, skills, and desires (Zuchdi, 2008). The combination of the three harmoniously causes a person or a community to leave dependence towards independence, and interdependence. Interdependence is very much needed in modern life because increasingly complex life can only be overcome collaboratively so harmonious relationships are needed through conflict resolution skills.

The results of research by FernandezRio, Sanz, Fernandez-Cando \& Santos (2017) show cooperative learning can increase student motivation, Cooperative learning that is applied sustainably can increase the type of motivation that is most self-determined, intrinsic motivation and identified regulations, in middle school students. Likewise, the research of Darnis \& Lafont (2015) which shows that cooperative learning with oral discussions between peers about the goals and strategies of the game facilitates the development of motor and tactical skills, while dyadic interactions show the superiority of dyadic conditions that are slightly asymmetrical. Students' perceptions after experiencing Cooperative Learning for a long period of time reflect four positive ideas (cooperation, interconnectedness, pleasure, novelty) and negative (disappointment).

Both positive and negative ideas must be considered when applying Cooperative Learning in physical education, because students experience it. Cooperative learning in physical Education and sports have also been proven to improve children's basic movement skills (Norito, Dlis, Hanif, \& Iqbal, 2019). In physical education, teachers need to position effective learning as the main goal of their teaching to help students learn to appreciate their own and others 'contributions, become more independent, adapt to peer teaching according to their own and others' needs, and think of abilities in terms of contributions and not just performance (Casey \& Fernandez-rio, 2019).

Physical education contains scenes of learning that are together, nuance of interaction between students, fun packed in cooperative games to give the experience of sensing the feelings of others, understanding the feelings of other people, to respect the feelings of others. The strong impact of cooperative learning on the growth of moral empathy and student tolerance rather than the impact of classical learning can be seen in the average score of empathy and tolerance in both learning models and field observations when students demonstrate the ability to accept the feelings of others, understand the presence of others, feel the presence of others, and do caring attitude towards others. This form of empathy is seen in the way students think, feel, and act on the stimulus of the motion task given to students. The creation of motivational ambience that is oriented to motion task could enforce participants to focus on the task rather than their own ego so they can justify their own ability based on the appeareance than through the improved social comparison.

In Physical Education learning, the cooperative learning intentionaly structuring model influences self-disclosure and selfawareness (Stiadi, Ma'mun, \& Juliantine, 2020). Physical education should choose learning strategy or model as an effort to facilitate emphaty and tolerance. Considering that these values concern about how individual exists in their social community. Cooperative learning is seen as the most suitable as its 
positive interdependence may assist learners to develop social values. Through cooperative learning, physical education enable students to build values by interacting with the others for a specific purpose.

Nevertheless, teachers are expected to manage classroom, therefore students are actively learning the subject matters as well as values of emphaty and tolerance. On the contrary, when classical method is used, social values are less likely to be used since learners tend to individualy work on their task although sitting with the others in the classroom. This finding is confirmed by study White (2010) found that a socio-culturally framed behaviour-management programme facilitated through the delivery of mediated cooperative-learning activities have a positive impact on pupil behaviour and selfregulation.

Furthermore, it is argued thatunderstanding about values is related to cognitive building. The better the cognitive process, the better the understanding of values. The purpose of this research is to obtain empirical evidence the impact of cognitive achievement and learning method in developing emphaty and tolerance during physical education. It is hypothesised that when students with higher achievement are directed to learn values through cooperative learning, they would learn it better than the reguler students. Relationship between physical education, cooperative learning, emphaty and tolerance in this study may be depicted in Figure 1.

Referring to the grand design of character education (Kemendiknas RI, 2010) describes that character education is a process of civilizing and empowering noble values in the environment of the education unit (school), family environment, and community environment. These noble values come from educational theories, educational psychology, socio-cultural values, religious teachings, Pancasila and the 1945 Constitution, and Law No. 20 of 2003 concerning the national education system, as well as the best experiences and real practices in everyday life. The process of civilizing and empowering these noble values also needs to be supported by the commitments and policies of relevant stakeholders including the support of necessary facilities and infrastructure.

In line with that Dewantara (1961) explains the embodiment of culture has three types or types: 1) recognize the sense of inner minds or moral, (2) recognize the progress of wishful thinking, and (3) recognize intelligence. Included in the culture of inner mind are religion, customs, state administration, social and so on. Culture of wishful thinking includes teaching, linguistics, science. Cultural types of intelligence include agriculture, industry, shipping, arts and others. Culture is the fruit of human action, arising from the maturity of the mind, the subtlety of feeling, the intelligence of the mind, and the power of the will. In the context of culture, Indonesian society is based on kinship, mutual cooperation, socialism, communalism. Every citizen is obliged to sacrifice and let himself live for the family, but the individual remains un ruled, as a 'lord' as well (Dewantara, 1961).

Modern socio-cultural theory emphasizes the child's opportunity to learn on social norms and practices. The social characteristics and cultural context when children develop affect their activities and participation. In discussions what is given by the community and culture creates and publishes social activities and interactions

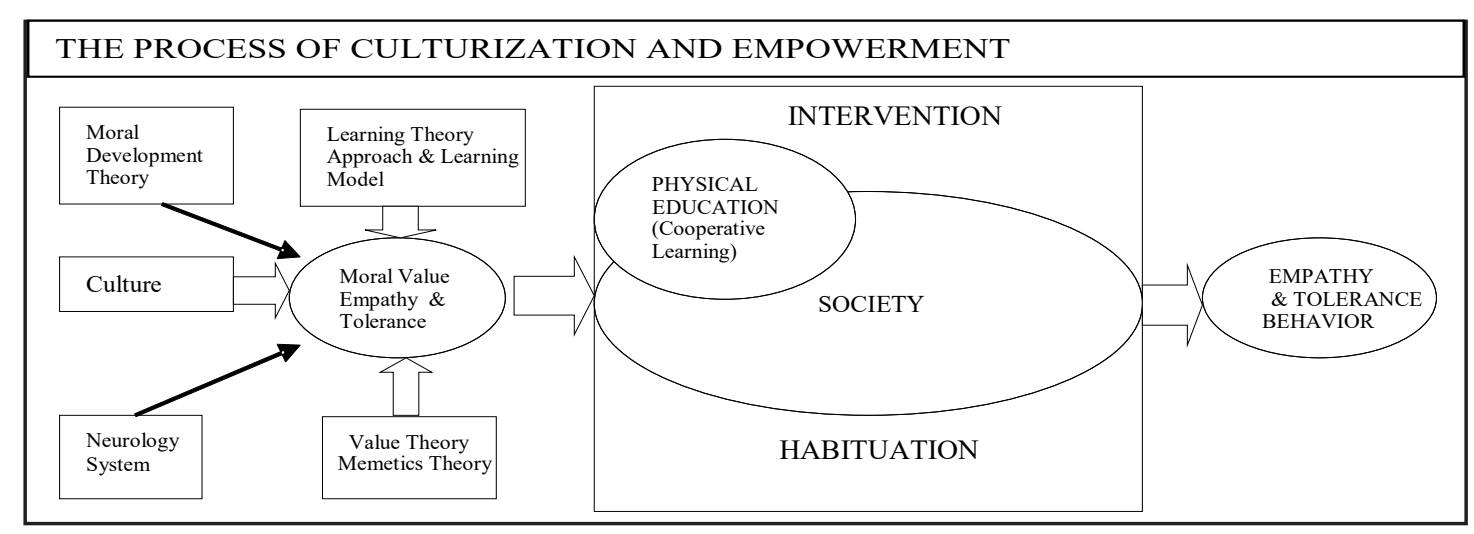

Figure 1. Relationship Between Culture Theory and Value Learning Apporach in the Development of Empathy and Tolerance 
that may be suitable for children. Socio-cultural theory also has potential implications for educational practice. First, it is suggested that students' knowledge needs to be conceptualized in the context of their ability to organize tasks with a supportive social interaction, and it needs to be rated in an interactions not in a separated appeareances.

Secondly, socio-cultural theories occurring in certain interactions (such as collaboration with more skilled friends), might benefit students. Third, the socio-cultural perspective is focusing their attention on how children learn to use cultural devices and different models that are used to teach children, know how to use devices like that, can have a different improvements for children's learning. Finally, the socio-cultural perspective provides a framework to observe and understand social interaction that takes place in educational devices and in formulating theories about how children make a behavioral changes.

In character development, the subject of physical education as an intermediary (as a medium and message), namely as a vehicle for culture and individual empowerment. With this understanding, the role of educational character can be carried out for all subjects, including physical education subjects. Schaps et al. (1997) agreed that the concept of affective development as an educational goal through physical education was introduced more than 160 years ago. A variety of recent research supports opinions about the preparation of education in the physical can support the development of student character. Weinberg \& Gould (2003) states that sports extracurricular activities have the potential to connect children to a positive behaviour, on several grounds: first, sports intrinsically motivates adolescents, secondly, it involves a continuous attempt to participate towards the desired goals, third, sports requires a groups of experiences, makes an adaptation, and learning to overcome problems. Research has also proven the fact of adolescent participation in sports activities could reduce criminal behavior.

Character building is not a process of finding various kinds of rules and good traits, but a process that requires changes in the cognitive structure and stimulation of the social environment (Martens, 2004; Lickona, 1991). Furthermore, the development and formation of a person's character is influenced by the ability of cognition and the ability to capture while interacting with the socio-cultural environment. This result is also in line with the statement that a person's character is formed not only because of imitation through observation, but can also be taught through sports situations, exercise, and physical activity (Weinberg \& Gould, 2003).

Thus, participating in sports activities does not automatically form individual values as internalization theory views, but what is considered as character values must be organized, constructed, and transformed into the basic structure of reasoning of individuals who participate in them (Stornes \& Ommundsen, 2004; Stuntz \& Weiss, 2003). Telama also states that although not many research results have shown the effect of physical education on students 'moral development, but it can be stated from a number of studies that physical education influences students' moral development (Auweele, Bakker, Biddle, Durand, \& Seiler, 1998). This effect on moral development is very dependent on the style and method of physical education that teachers taught to their students. In another part it is also stated that one's morality has three components, namely: affective component, cognitive component, and behavioral component. The orientation of the moral development of students is achieved through the relationship of interaction between students and other students.

The core of the process is the physical education teacher designs and organizes the teaching process so that it fosters social interaction and adds discussion involvement, negotiation, and consensus-seeking. Knowledge about morals is obtained through affective and cognitive interaction in the form of group discussions before, on the sidelines of learning, and at the end of learning.

Bandura argues that in social situations, humans often learn much faster just by observing people's behavior. Observation teaches a number of possible consequences of a new behavior by paying attention to what will happen when others try it (Crain, 2015). Bandura (1977) further emphasized that character attitudes and behaviors (in this case empathy and tolerance) are learned through modeling or observational learning, reinforcement, and social comparison. This approach shows that a person's social learning history determines the level of moral 
behavior. Learning through observation is usually cognitive (Skinner), but Bandura prefers to call it a vicarious reinforcement process (reinforcement through empathic observation, feeling as if we are doing it).

Such reinforcement is included in the cognitive process, formulating expectations of the results of behavior without acting directly from the situation itself. Furthermore according to Vygotsky (Crain, 2015), developmental changes occur in the internalization of social processes. The stages of moral development are hierarchical integration meaning that if a person rises to a higher stage it will be reintegrated with the structure of thinking at a lower stage (Crain, 2015). Value memes is a deep decision system for humans, not human types, which is distinguished by age, social class, ethnicity, culture, society and time period (Rosaldo, 2004).

An education system that is suitable for producing intelligent quality and noble character (good character) according to Zuchdi (2008) is a humanist education system, which is able to position students as individuals and community members who need to be assisted and encouraged to have an effective habits, a blend of knowledge, skills, and desires. The combination of the three harmoniously causes a person or a community to leave dependence towards independence, and interdependence. Interdependence is indispensable in modern life because increasingly complex life can only be overcome collaboratively. For that we need a harmonious relationship. One of the skills to build harmonious relationships is the skill of resolving conflicts, learning with groups and creating task assignments that trigger conflict and dilemmas can be agents for learning empathy and tolerance.

The learning model by applying cooperative strategies and experiential approaches is quite appropriate to support what Darmiyati calls a humanist education system. The planned cooperative procedure with the stages of the experiential learning cycle proved to be appropriate for developing student empathy and tolerance. More than that physical education learning with experiential learning prioritizes psychological changes and development when students interact with environmental experiences to form moral reasoning (Weinberg \& Gould, 2003).
During the learning process, the learning situation requires students to determine an action to help their friends who cannot or do not help. As an example; help a group of friends with fewer pushup frequencies by counting more, or letting their friend do the assignment as a moral act that is right or wrong. In other words, in learning students are encouraged to be able to find reasons that underlie moral decisions that aim to control action. This is necessary so that a person can truly understand the moral decisions he takes, can identify good reasons that must be accepted and bad reasons that must be rejected or changed. Learners must be able to formulate changes that need to be made. A good reason is that which contributes to overcoming problematic situations.

This method allows intellectual development, fosters freedom of thought, and can integrate education processes and outcomes in harmony. In the learning process various moral dilemmas are provided. Like helping friends in other groups who fall but do not win, or do not help and can win. The concept of morality needs to be integrated with experience in social life. Moral thinking can be developed, among other things, by moral dilemmas, which require the ability of students to make decisions in very dilemmatic conditions.

In this way, moral thinking can develop from the lowest level of obedience to authority for fear of physical punishment, to higher levels, which are oriented towards fulfilling personal desires, loyalty to groups, carrying out tasks in society according to regulations or law, up to the highest, which supports truth or essential values, especially regarding honesty, justice, respect for human rights, and social care. Significant differences in empathy and tolerance scores in both international and regular class types show that cognitive levels greatly influence the ability to perceive moral concepts, such as the opinion of adherents of structural development emphasizing that the ability to reason morally depends on the cognitive level and mental development of people who are concerned (for example, the child's ability to think concretely or abstractly). Moral reasoning and behavior depend on the level of cognitive development of the individual (Weinberg \& Gould, 2003).

The discussion from a neurological point of view found that empathy and tolerance are 
always related to emotions. Meanwhile, emotions are more easily understood as emotional states, which have two major components, namely: 1) physical sensations from emotions; and 2) cognitive experience or feelings from the emotions themselves (Elias \& Saucier, 2006). The development of this emotional state theory is based on cognitive - interpretation of events that are responded to emotionally. This theory states that the brain constructs emotional construct simultaneously to the sensations of other experiences. The brain gives signals from periphery, interpret, and translate them into emotional states. Thus, the same emotion can produce different feelings depending on the context of the event.

This theory states that cognitive processes are important in producing emotional conditions and the role of periphery (in the brain) is tasked with looking at organisms as potential situations. The flow of understanding of the emotional state based on this theory is: emotionally provocative stimulus gives rise to psychological arousal cognitive assessment of the situation and finally emotion. Cooperative learning provides situations that give rise to proper empathy and tolerance. For example: diverse groupings, joint experiences that require all students to interact with other students. Stimulation of a situation that gives rise to empathy and tolerance is provided by cooperative learning such as providing different tasks for each group member, warming up in the introduction to learning with various physical activities that require collaboration. Thus students will think automatically of what is perceived so that feelings of empathy and tolerance will emerge.

Visceral simulations relating to the inner-mind world of others are augmented by thinking based on conclusions about what other people's values, beliefs, and what is planned. In developmental psychology, this ability is called "theory of mind." The theory of mind is supported by one area of the brain, specifically: The Prefrontal Cortex (PFC) is the part of the brain that is tucked behind the forehead, around the bottom of the brow, and close to the ACC and insula, as well as others structure in the emotional central switchboard of the brain, called the limbic system. That part is the area of the brain that is activated, when someone enters into his own mental state and when thinking about other people.

Discussion of Socio-Anthropology Culture found that the existence of character education through learning the values of physical activities in physical education learning is also influenced by the level of cultural socioanthropology prevailing in a community. This shows that physical education in the effort to form the values of empathy and tolerance, as an individual personal character trait, is strongly influenced by implicit and explicit cultural structures. As an indicator of social interaction, moral tolerance and empathy are strongly influenced by the social environment that is formed.

Tolerance and empathy as a result of an interaction between the affective, cognitive, and behavioral domains of individuals requires a place that is relevant and conducive to the moral values that are believed, beliefs, and symbols or mores that apply in society. Culture that shapes behavior and at the same time influences people's faith and beliefs, influences moral empathy and tolerance. In addition, physical activities based on values also need to be in line and relevant to the conditions and cultural demands of the community. The existence of a social system is also related to other social institutions, such as the legal system that is put in place will also be associated with the formation of moral empathy and tolerance.

When the legal system does not work in accordance with the ideals of the law, such as the principle of justice, moral tolerance and empathy will also be damaged. The unclear legal system will affect the value of empathy and tolerance in society. Likewise, the existence of economic interference and technological progress and the existence of a political system that is not clear and unequivocal also will affect the existence of physical activity, but even at the same time it will also affect moral tolerance and empathy. This attachment then arises in the discussion of multiculturalism. It is interesting to continue to be studied and explored in the multicultural cultural constellation that will undermine the cultural values that exist and are believed by the public.

This study also found a practical guide to learning the value of empathy and tolerance through physical education, namely: (1) discussion and reflection of the moral values 
of empathy and tolerance; (2) parsing the components of empathy and tolerance (for example: feelings of compassion, accepting other students, presenting other students, recognizing other students, giving responses); (3) dividing students into small groups; (4) creating interaction between students when learning a task (eg increasing the difficulty of a task of learning motion, increasing the number of players, complicating the rules of play; (5) creating group discussion pauses to foster empathy and tolerance through the ngreti (understanding), ngeroso (feeling), ngelakoni (doing) pathways; (6 ) develops learning tasks of motion/physical activity; (7) provides reinforcement to students who practice empathy and tolerance, and suspends the involvement of students who do not practice empathy and tolerance; (8) confirms and resumes student behavior, feelings, and thoughts about empathy and tolerance as well as the task of learning the motion carried out, as shown in Figure 2.

\section{CONCLUSION}

The evidence gathered in this research leads to a conclusion that there is a significant different impact between cooperative and classical learning, whereas students could learn better to value emphaty and tolerant in cooperative learning. Students who have higher cognitive achievement seems to learn emphaty more meaningfully than those in average achievement. The interaction effect indicated that higher cognitive ability in cooperative learning will value emphaty and tolerant more significantly than the counterpart. The improvement of understanding on the philosophy of physical education for the school teachers, particularly related to the development of the objective of physical education should then be directed to contribute to the building of character of emphaty and tolerant. Teacher education, consequently, should include this cooperative model in the curriculum of preservice teacher education. However, teachers

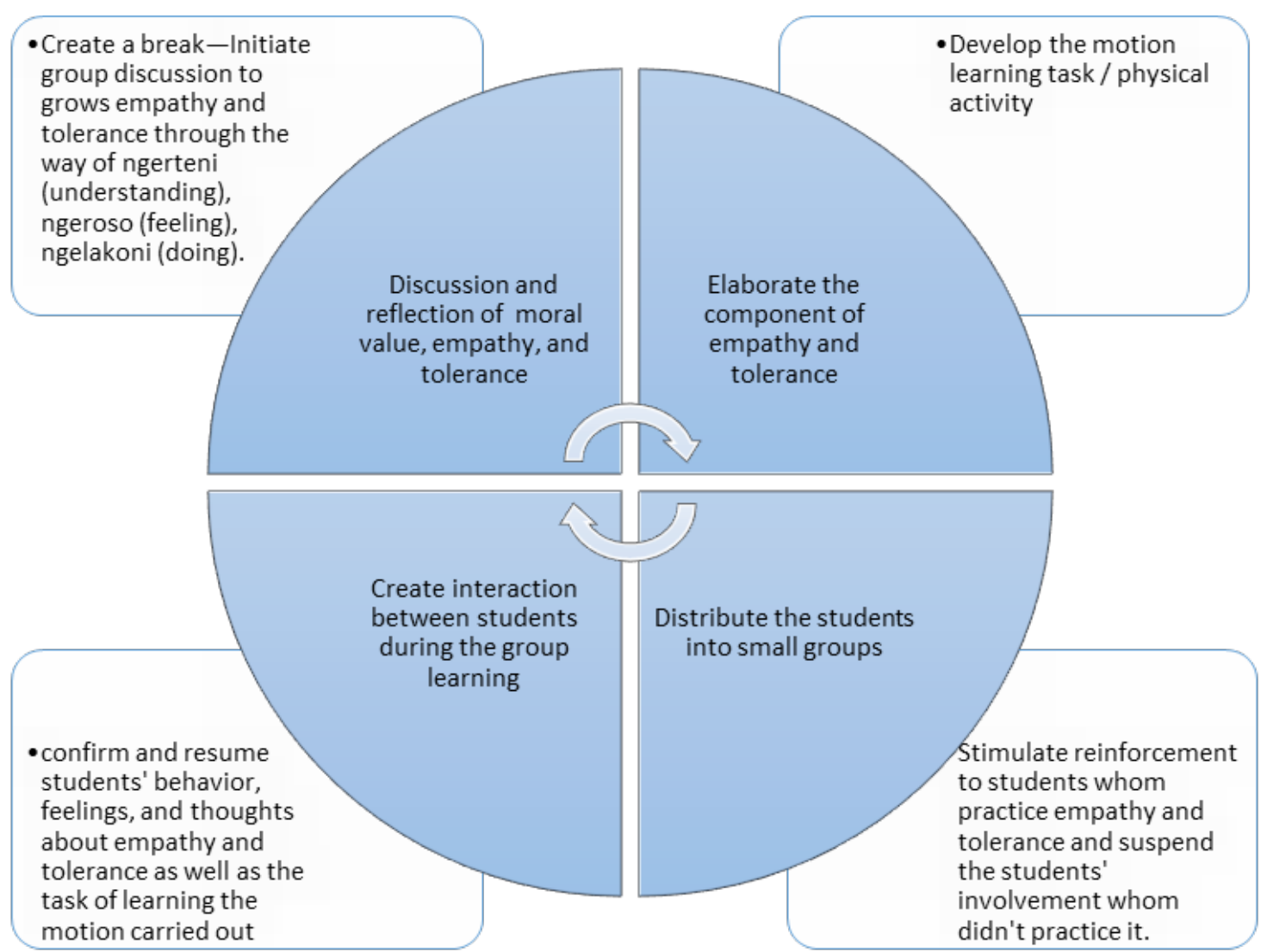

Figure 2. Interrelation Principle of Cooperative Learning for Empathy and Tolerance Learning in Physical Education 
need to be motivated to implement such character education in physical education. This can be done in collaboration with support by educators at the teacher training institute.

\section{REFERENCES}

Allport, G. W. (1960). Personality: A psychological interpretation. New York, NY: Henry Holt \& Company.

Auweele, V. Y., Bakker, F., Biddle, S. J. H., Durand, V. M., \& Seiler, R. (1998). Psychology for physical education. Champaign, IL: Human Kinetics.

Bolton, R. (1979). People skills: How to assert your self, listen to others, and resolve conflicts. New Jersy, NJ: Prentice Hall Inc.

Bores-garcía, D., Hortigüela-alcalá, D., Fernandez-rio, F. J., González-calvo, G., \& Barba-martín, R. (2020). Research on cooperative learning in physical education: Systematic review of the last five years. Research Quarterly for Exercise and Sport, 00(00), 1-10. doi:10.1 080/02701367.2020.1719276.

Bandura, A. (1977). Social learning theory. New York, NY: General Learning Press.

Batson, D. C., Thompson, E. R, Seuferling, G., Whitney, H., \& Strongman, J. A. (1999). Moral hypocrisy: Appearing moral to oneself without being so. Journal of Personality and Social Psychology, 77(3), 525-537. doi:10.1037/00223514.77.3.525.

Bredemeier, B. J. L. \& Shields, D. L. L. (2006). Sport and character development. Journal of physical activity \& health, 7(1), 1-8. doi:10.1123/jpah.3.2.255.

Casey, A., \& Fernandez-rio, J. (2019). Cooperative learning and the affective domain. Journal of Physical Education, Recreation and Dance, 90(3), 12-17. doi :10.1080/07303084.2019.1559671.

Certel, Z., Bahadır, Z., Kabaca, H. E., \& Seraki, A. S. (2018). Professional experience, tolerance, empathy and reading interests as variables predicting cognitive flexibilities of physical education teachers. International Journal on New Trends in Education and Their Implication, 9(3), 41-51. www.ijonte.org.

Clifford, C., \& Feezell, R. (1997). Coaching for character. Champaign, IL: Human Kinetics.

Crain, W. (2015). Theoris of development, concepts and applications. New York, NY: Psychology Press.

Darnis, F., \& Lafont, L. (2015). Cooperative learning and dyadic interactions: two modes of knowledge construction in socio-constructivist settings for teamsport teaching. Physical Education and Sport Pedagogy, 20(5), 459-473. doi:10. 1080/17408989.2013.803528.

Denzin, N. K., \& Lincoln, Y. S. (Eds). (1994). Handbook of qualitative research. California, CA: Thousand Oaks.

Dewantara, K. H. (1977). Bagian pertama: Pendidikan. [Fisrt part: Education]. Yogyakarta: Majelis Luhur Persatuan Taman Siswa.

Ebbeck, V., \& Gibbons, S. L. (1998). The effect of a team building program on the selfconceptions of grade 6 and 7 physical education students. Journal of Sport and Exercise Psychology, 20(3), 300-310. https://www.cabdirect.org/cabdirect/ abstract/19981812704.

Elias, L. J., \& Saucier, D. M. (2006). Neuropsychology: Clinical and experimental foundations. Harlow, UK: Persoen/Allyn \& Bacon.

Fernandez-Rio, J., Sanz, N., FernandezCando, J., \& Santos, L. (2017). Impact of a sustained cooperative learning intervention on student motivation. Journal Physical Education and Sport Pedagogy, 22(1), 89-105. doi:10.1080/17 408989.2015.1123238.

Freeman, W. H. (2001). Physical education and sport: In a changing society. Boston, MA: 
Allyn and Bacon A Pearson Education Company.

Grineski, S. (1996). Cooperative learning in physical education. Champaign, IL: Human Kinetics.

Hardman, K. (2003). Worldwide survey on the state and status of physical education in school: Foundations for deconstruction and reconstruction of physical education, Issues and directions (pp.13-34). Schorndorf: Hofmann.

Harrison, J. M., \& Blakemore, C. L. (1983). Instructional strategies for secondary school physical education. Dubuque, IA: Wm.C. Brown Publishers.

Johnson, D. W., Johnson, R. T., \& Holubec, E. J. (1993). Cooperation in the classroom $\left(6^{\text {th }}\right.$ ed.) Edina, MN: Interaction Book Company.

Johnson, D. W., Johnson, F. P., \& Smith, K. A., (2013). Cooperative learning: Improving university instruction by basing practice on validated theory. Journal of Excellence in University Teaching, 25(3-4), 85-118.

Jones, C. (2005). Character, virtue and physical education. European Physical Education Review, 11(2), 139-151. doi:10.1177/1356336X05052893.

Kagan, S. (1994). Cooperative learning. San Clemente, CA: Kagan Publishing.

Kemendiknas RI. (2010) Desain induk pendidikan karakter. [Grand design character education]. Jakarta: Author.

Kleiber, D. A., \& Roberts, G. C. (1981). The effect of sport experience in the development of social character: An exploratory investigation. Journal of Sport Psychology, 3(2), 114-122. doi:10.1123/ jsp.3.2.114.

Knauth, T. (2010). Tolerance: A key concept for dealing with cultural and religious diversity in education. http://www.theewc. org/uploads/content/education.

Kurtines, W. M., Azmitia, M., \& Gewirtz, J.
L. (Eds.). (1992). The role of values in psychology and human development. New York, NY: John Wiley \& Sons.

Lickona, T. (1991). Educating for character. New York, NY: Bantam Books.

Maksum, A. (2007). Psikologi olahraga: Teori dan aplikasi. [Sports psychology: Theory and application]. Surabaya: Fakultas Ilmu Keolahragaan, Universitas Negeri Surabaya.

Maksum, A. (2005). Olahraga membentuk karakter: Fakta atau mitos. [Sports build character: Fact or myth]. Jurnal Ordik, 3(1), 23-30.

Martens, R. (2004). Succesful coaching ( ${ }^{\text {rd }}$ ed). Champaign, IL: Human Kinetics.

Miller, B., Roberts, G. C., \& Ommundsen, Y. (2005). Effect of perceived motivational climate on moral functioning, team moral atmosphere perceptions, and the legitimacy of intentionally injurious acts among competitive youth football players. Journal of Sport and Exercise Psychology, 6(4), 461-477. doi:10.1016/j. psychsport.2004.04.003.

Norito, T. B., Dlis, F., Hanif, A. S., \& Iqbal, M. (2019). Implementing cooperative learning in physical education and sport to improve children. Journal of Education, Healt, and Sport, 9(7), 390403. doi:10.5281/zenodo.3346970.

Orlick, T. D. (1981). Positive socialization via cooperative games. Developmental Psychology, 17(4), 426-429. doi:10.1037/0012-1649.17.4.426.

Pfeifer, J., Brown, C., \& Juvonen, J. (2007). Teaching tolerance in schools: Lessons learned since brown v. board of education about the development and reduction of children's prejudice. Journal Society for Research in Child Development Jurnal, 21(2), 3-23. doi:10.1002/j.2379-3988.2007.tb00051.x.

Pusat Bahasa Departemen Pendidikan Nasional Republik Indonesia. (2008). Kamus Besar 
Bahasa Indonesia. [Indonesian Language Dictionary]. http://bahasa.kemdiknas. go.id/kbbi/index.php.

Rokeach, M. (1973). The nature of human values. New York, NY: Collier Macmillan Publishers.

Rosaldo, C. (2004). Building your leadership team: Value systems memetics and education- a spiral dynamics approach. http://www.EdChange.org/multicultural.

Shields, D. L. L., \& Bredemeier, B. J. L. (1995). Character development and physical activity. Champaign, IL: Human Kinetics.

Schaps, E., Battistich, V., \& Solomon, D. (1997). School as a caring community: A key to character education. In A. Molnar (Eds.). The construction of children's character, part II: $96^{\text {th }}$ yearbook of the National Society for the Study of Education. Chicago: University of Chicago Press, pp. 127-139.

Slavin, R. E. (2011). Cooperative learning, theory, reasearch and practice (N.Yusron, Trans). Bandung: Nusa Media. (Original work published 2005).

Stornes, T., \& Ommundsen, Y. (2004). Achievement goals, motivational climate and sportspersonship: A study of young handball players. Scandinavian Journal of Educational Research, 48(2), 205-221. do i:10.1080/0031383042000198512.

Stiadi, D., Ma'mun, A., \& Juliantine, T. (2020). The effect of cooperative learning intentionally structuring model on self-disclosure and self-awareness in physical education learning at School Dendy. Jurnal Pendidikan Jasmani dan Olahraga, 5(1), 22-28. doi:10.17509/jpjo. v5i1.23540.

Sugiman, S., Retnowati, E., Ayres, P., \& Murdanu, M. (2019). Learning goal-free problems: Collaboratively or individually?
Cakrawala Pendidikan, 38(3), 590-600. doi:10.21831/cp.v38i3.26914.

Stueber, K. (2008). Emphaty: Stanford Encyclopedia of Philosophy. http://plato. stanford.edu/entries/empathy.

Stuntz, C. P., \& Weiss, M. R. (2003). Influence of social goal orientations and peers on unsportsmanlike play. Research Quarterly for Exercise and Sport, 74(4), 421-435. do i:10.1080/02701367.2003.10609112.

UNESCO. (1995, 25 October - 16 November). Declaration of principles on tolerance. Declared at the twenty-eighth session of the General Conference, Paris. http://portal.unesco.org/en/ev.phpURL ID $=13175 \&$ URL DO $=$ DO TOPIC\&URL SECTION=201.html

Weinberg, R. S., \& Gould, D. (2003). Foundation of sport and exercise phsychology (Third ed.). Champaign, IL: Human Kinetics.

White, R. (2010). Building schools of character: The development, implementation, and evaluation of a school-based character education programme designed to promote cooperative learning and reduce anti-social behavior (Doctoral thesis, Durham University). http://etheses.dur. ac.uk/189/.

Wuest, D. A., \& Bucher, C. A. (1995). Foundations of physical education and sport. St Louis, Missouri: Mosby-Year Book, Inc.

Yigiter, K., \& Pelin, U. (2013). Effect of the sport training on empathy ability of the vocational school students in Turkey. Journal of Education and Practise, 4(11), 210-214. https://www.iiste.org/Journals/ index.php/JEP/article/view/6479.

Zuchdi, D. (2008). Humanisasi pendidikan. [Humanization of education]. Jakarta: Bumi Aksara. 